\title{
III. On a new law, analogous to those known under the names, law of Avogadro and law of Dulong and Petit
}

\section{J.A. Groshans}

To cite this article: J.A. Groshans (1885) III. On a new law, analogous to those known under the names, law of Avogadro and law of Dulong and Petit, Philosophical Magazine Series 5, 20:122, 19-30, DOI: $10.1080 / 14786448508627719$

To link to this article: http://dx.doi.org/10.1080/14786448508627719

冓 Published online: 29 Apr 2009.

Submit your article to this journal $[\pi$

Џll Article views: 3

Q View related articles $\square$ 


\section{[ 19 ]}

III. On a New Law, analogous to those known under the names, Law of Avogadro and Law of Dulong and Petit. By J. A. Groshanst.

WHEN the boiling-points and densities of substances are compared with their atomic composition, we find that there is a law regulating this relationship which is analogous to the laws mentioned in the title of this paper.

I have called this law, The Law of "Density Numbers." The density numbers (Densitätzahlen) form a new class of constants, which present themselves as attributes of the elements, and are of the following nature.

They are whole numbers. Each element possesses only one, which may be easily determined; but two or more elements may possess the same number.

Table I. contains a list of these new constants so far as they have yet been determined. An asterisk affixed to a number denotes that this is the number which appears to me probably the correct one, but that verification is necessary. I venture to hope that, when the scientific public realize the interesting nature of this new law, the constants given in the Table will be rigorously verified, and the gaps at present so numerous will then be filled up.

TABLE I.

Density-numbers of the Elements already determined.

\begin{tabular}{|c|c|c|c|c|c|c|c|}
\hline $\begin{array}{l}\mathrm{C} \\
\mathrm{H} \\
\mathrm{O}\end{array}$ & $\begin{array}{l}1 \\
1 \\
1\end{array}$ & $\begin{array}{l}\mathrm{Li} \\
\mathrm{Be} \\
\mathrm{S}\end{array}$ & $\begin{array}{l}2 \\
2 \\
2\end{array}$ & $\begin{array}{l}\mathbf{B}^{*} \\
\mathbf{N} \\
\mathbf{P}\end{array}$ & $\begin{array}{l}3 \\
3 \\
3\end{array}$ & $\begin{array}{l}\mathbf{F} \\
\mathbf{N a} \\
\mathrm{Al} \\
\mathbf{S i} \\
\mathrm{Cl}\end{array}$ & $\begin{array}{l}4 \\
4 \\
4 \\
4 \\
4\end{array}$ \\
\hline $\begin{array}{l}\mathrm{Mg} \\
\mathrm{K}\end{array}$ & $\begin{array}{l}5 \\
5\end{array}$ & $\mathrm{Ca}$ & 7 & $\begin{array}{l}\nabla^{*} \\
\text { As }_{\text {Se }}\end{array}$ & $\begin{array}{l}8 \\
8 \\
8\end{array}$ & $\begin{array}{l}\mathrm{Cr} \\
\mathrm{Mn} \\
\mathrm{Fe} \\
\mathrm{Br}\end{array}$ & $\begin{array}{l}9 \\
9 \\
9 \\
9\end{array}$ \\
\hline & $\begin{array}{l}\mathrm{Ni} \\
\mathrm{Co} \\
\mathrm{Cu} \\
\mathrm{Zn} \\
\mathrm{Rb}^{*}\end{array}$ & $\begin{array}{l}11 \\
11 \\
11 \\
11 \\
11\end{array}$ & & $\begin{array}{l}\mathrm{Sr} \\
\mathbf{N b} \\
\mathrm{Sb}\end{array}$ & $\begin{array}{l}13 \\
13 \\
13\end{array}$ & $\begin{array}{l}\mathrm{Zr}^{*} \\
\mathrm{Sn} \\
\mathrm{Te} \\
\mathrm{I}\end{array}$ & $\begin{array}{l}14 \\
14 \\
14 \\
14\end{array}$ \\
\hline & $\begin{array}{l}P^{*} \\
\stackrel{A g}{ } \\
\mathrm{Cd}\end{array}$ & $\begin{array}{l}16 \\
16 \\
16\end{array}$ & & $\begin{array}{l}\mathrm{M} o^{*} \\
\mathrm{Cs}^{*}\end{array}$ & $\begin{array}{l}17 \\
17\end{array}$ & $\mathbf{B a}$ & 19 \\
\hline & $\begin{array}{l}\mathrm{Ta}^{*} \\
\mathrm{Bi}^{*}\end{array}$ & $\begin{array}{l}23 \\
23\end{array}$ & & $\begin{array}{l}\mathrm{Hg} \\
\mathrm{Tl}^{*}\end{array}$ & $\begin{array}{l}26 \\
26\end{array}$ & $\begin{array}{l}\mathrm{W}^{*} \\
\mathrm{Pt}^{*} \\
\mathrm{~Pb}\end{array}$ & $\begin{array}{l}29 \\
29 \\
29\end{array}$ \\
\hline
\end{tabular}

+ Communicated by the Author. Translated by W. W.J. Nicol, M.A., D.Sc., F.R.S.E. 
The density-numbers of the elements increase with their atomic weights, but are not proportional to these.

The exact nature of these numbers is not yet distinctly made out; but the following provisional hypothesis, which, I believe, may altimately prove to be correct, will help in forming a conception of their nature.

According to this hypothesis, carbon, hydrogen, and oxygen are simple bodies; but the other elements are compounds of other simple substances, the number of atoms of which is shown by the density-number of each element.

The law itself may be enunciated in the following simple form :-

"The densities of substances are proportional to the densitynumbers."

For example, in the case of two compounds of carbon, hydrogen, and oxygen (comparable with one another), and with the formulæ $\mathrm{C}_{p} \mathrm{H}_{q} \mathrm{O}_{r}$ and $\mathrm{C}_{p^{\prime}} \mathrm{H}_{q^{\prime}} \mathrm{O}_{r^{\prime}}$, if $u$ and $n^{\prime}$ equal the sum of $p+q+r$ and $p^{\prime}+q^{\prime}+r^{\prime}$ respectively, and the densities are $\delta$ and $\delta^{\prime}$,

$$
\frac{\delta}{\delta^{\prime}}=\frac{n}{n^{\prime}} \text { or } \frac{n}{\delta}=\frac{n^{\prime}}{\delta^{\prime}}=\text { constant }=l .
$$

The law of Avogadro leads in the same way to a constant; for if the vapour-density of a substance at $0^{\circ} \mathrm{C}$. and 760 millim. equals $\mathrm{D}$, and its molecular weight is $a$, then

$$
\frac{\mathrm{D}}{\mathrm{D}^{\prime}}=\frac{a}{a^{\prime}} \text {, whence } \frac{a}{\overline{\mathrm{D}}}=\text { constant. }
$$

This constant is unique, and is true of all bodies which can be converted into vapour. Such is not the case, however, with the law of molecular specific heats $(a \times c)$. This constant differs in the various groups of compounds; each group possesses a single constant which is peculiar to it. The law of density-numbers resembles in this respect that of Dulong and Petit.

This new law is applicable to substances in every state of aggregation; but it is necessary that the substances should be compared under similar conditions, such as :-

(1) as gases at the boiling-point;

(2) as liquids at the boiling-point;

(3) as solids (crystals hydrated or anhydrous);

(4) in very dilute solutions.

When dealing with substances which contain only carbon, hydrogen, and oxygen, I shall continue to use the letter $n$ for the sum of the numbers of density; but when other elements enter into the composition of a body, I shall employ B to indicate the above sum. 
In the following pages I shall endeavour to give a fairly complete account of the numerous applications of this law, the study of which bas occupied my leisure hours for many years, ever since a happy chance disclosed to me a special case, an account of which was published in Poggendorff's Annalen, lxxviii. (1849) p. 112.

When the law is applied to hydrated crystalline salts containing the same number of molecules of water, a hitherto concealed relationship is discovered.

If $B$ is the sum of the numbers of density of the salt, and $\delta$ its density, it is found that $\frac{\mathrm{B}}{\delta}=k$ for all salts with similar formulæ and containing the same amount of water of crystallization, as will be seen from Table II., which contains the data relating to six salts of the general formula $\mathrm{MR}_{2} \cdot 6 \mathrm{H}_{2} \mathrm{O}$. $B$ in this case is equal to the sum of the density-numbers for the anhydrous salt plus 18 , which is the value of $\mathrm{B}$ or $n$ for $\mathrm{H}_{2} \mathrm{O}$. Thus, a reference to Table $\mathrm{I}$. show's that $\mathrm{CaCl}_{2} 6 \mathrm{H}_{2} \mathrm{O}$ has $\mathrm{B}=7+2(4)+6(3)=33$.

TABLE II.

\begin{tabular}{|c|c|c|c|}
\hline Salt. & B. & $\delta$. & $k$. \\
\hline $\mathrm{SrCl}_{2}, 6 \mathrm{aq} \ldots \ldots \ldots$ & $21+18=39$ & 1.964 & $19 \cdot 86$ \\
\hline $\mathrm{CaCl}_{2}, \ldots \ldots \ldots$ & $15+18=33$ & $1 \cdot 654$ & $19 \cdot 95$ \\
\hline $\mathrm{CoCl}_{2}, \ldots \ldots$. & $19+18=37$ & $1 \cdot 84$ & $20 \cdot 11$ \\
\hline $\mathrm{MgCl}_{2}, \ldots \ldots \ldots$ & $13+18=31$ & $1 \cdot 562$ & $19 \cdot 85$ \\
\hline $\mathrm{Ni}\left(\mathrm{NO}_{3}\right)_{2}, 6 \mathrm{aq} \ldots$. & $23+18=41$ & $2 \cdot 05$ & $20 \cdot 00$ \\
\hline $\mathrm{Zn}\left(\mathrm{NO}_{3}\right)_{2}, y \quad \ldots$ & $23+18=41$ & 2.065 & $19 \cdot 85$ \\
\hline
\end{tabular}

The data for this table and for others are taken from the collections made by Landolt and Börnstein, Clarke's 'Constants of Nature,' and the experiments of Bödeker, Playfair and Joule, Schröder, Topsoë, and others on the densities of compounds.

The table shows clearly enough that the volumes $k$ are practically equal, and by means of such groups it is possible to determine the density-numbers for the various elements. All the density-numbers in Table I. have been determined by employing the data given by hydrated salts and (where possible) the boiling-points, and the densities of aqueous solutions as well as all other available analogous data.

At this point I shall return to Table I., in order to bring forward some views of a more general nature regarding the density-numbers. 


\section{Triads.}

The name of Triads has been given to groups of elements such as chlorine, bromine, and iodine, or phosphorus, arsenic, and antimony; and I shall retain the name, notwithstanding the fact that each group contains at least four elements. Of these four elements three are characteristic, while the fourth may be regarded as a precursor, which, although participating in the nature of the three principal elements, yet is distinct, and possesses properties more or less different.

The following table contains twenty elements arranged in five triads. I have chosen those which appear to be complete, and have added to the table the atomic weights and the density-numbers with their differences.

The density-numbers of the three principal elements in each triad have a constant difference, which is in two of the groups five units, in the other three six units.

TABLE III.—Triads.

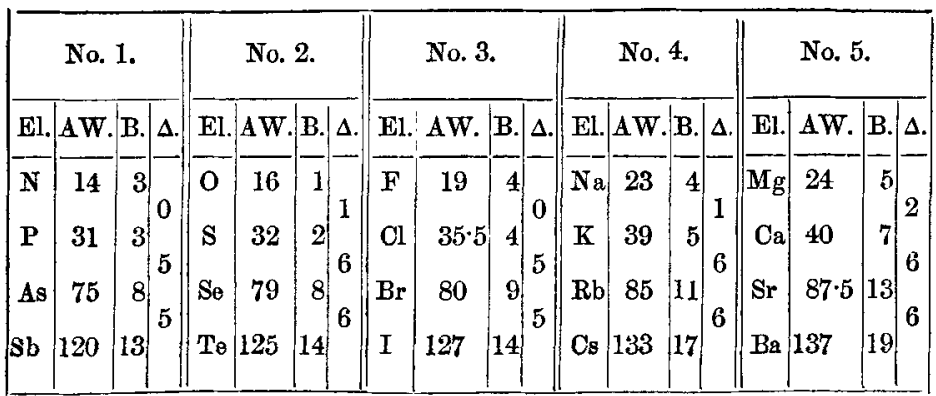

$\mathrm{El}=$ element. $\mathrm{AW}=$ atomic weight. $\mathrm{B}=$ density-number.

$\Delta=$ difference of density-numbers.

The differences in the atomic weights of the three principal elements all lie between 44 and $49 \cdot 5$. The equality of this difference in the same triad is only approximate; and the opinion, formerly held, of their exact equality has been rendered untenable by the experiments of Stas and Marignac, as shown in Table IV.

TABLE IV.

\begin{tabular}{|c|c|c|c|c|}
\hline I. & II. & III. & IV. & V. \\
\hline 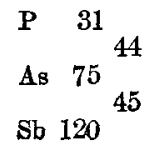 & $\begin{array}{lll}\text { S } & 32 & \\
& & 47 \\
\text { So } & 79 & \\
& & 46 \\
\text { To } & 125 & \end{array}$ & $\begin{array}{lll}\text { Cl } & 35 \cdot 5 \\
& & 44 \cdot 5 \\
\text { Br } & 80 & \\
\text { I } & 127 & 47\end{array}$ & $\begin{array}{cc}\text { K } & 39 \\
& 46 \cdot 2 \\
\text { Rb } & 85 \cdot 2 \\
& 47 \cdot 5 \\
\text { Cs } & 132 \cdot 7\end{array}$ & $\begin{array}{cc}\mathrm{Ca} & 40 \\
& 47 \cdot 5 \\
\mathrm{Sr} & 87 \cdot 5 \\
& 49 \cdot 5 \\
\mathrm{Ba} & 137\end{array}$ \\
\hline
\end{tabular}


The differences in the atomic weights between the precursors and the first member of the triad proper varies from 16 to 17 , and the difference in density-numbers from 0 to 2 , as in Table V.

TABLE V.

\begin{tabular}{|c|c|c|c|c|}
\hline \multicolumn{5}{|c|}{ Atomic Weights. } \\
\hline J. & II. & III. & IV. & V. \\
\hline $\begin{array}{ll}\text { N } & 14 \\
\text { P } & 31\end{array}$ & $\begin{array}{ll}\text { o } & 16 \\
\text { s } & 32\end{array}$ & $\begin{array}{ll}\text { F } & 19 \\
\text { Cl } & 35 \cdot 5\end{array}$ & $\begin{array}{lll}\text { Na } & 23 & \\
K & 39\end{array}$ & $\begin{array}{ll}\mathrm{Mg} & 24 \\
\mathrm{Ca} & 40\end{array}$ \\
\hline \multicolumn{5}{|c|}{ Density-numbers. } \\
\hline $\begin{array}{l}N=3 \\
P=3\end{array} 0$ & $\begin{array}{l}0=1 \\
s=2\end{array}$ & $\begin{array}{l}\mathrm{F}=4 \\
\mathrm{Cl}=4\end{array} 0$ & $\begin{array}{l}\mathrm{Na}=4 \\
\mathrm{~K}=5\end{array}$ & $\begin{array}{l}\mathrm{Mg}=5 \\
\mathrm{Ca}=7\end{array}$ \\
\hline
\end{tabular}

Among the elements in Table I., besides those included in the above triads, are to be found groups of two or more elements which present the same properties as the triads.

Thus there are three pairs with the difference 16.

TABLE VI.

\begin{tabular}{|c|c|c|c|c|c|}
\hline $\begin{array}{l}\text { Atomic } \\
\text { weight. }\end{array}$ & $\begin{array}{l}\text { Density- } \\
\text { number. }\end{array}$ & $\begin{array}{l}\text { Atomic } \\
\text { weight. }\end{array}$ & $\begin{array}{l}\text { Density- } \\
\text { number. }\end{array}$ & $\begin{array}{l}\text { Atomic } \\
\text { weight. }\end{array}$ & $\begin{array}{l}\text { Density- } \\
\text { number. }\end{array}$ \\
\hline $\begin{array}{l}\mathrm{Li} \quad 7 \\
{ } 16 \\
\mathrm{Na} 23\end{array}$ & $\begin{array}{ll}2 & 2 \\
4 & \end{array}$ & $\begin{array}{l}\text { В } 11 \\
\text { Al } 27\end{array}$ & $\begin{array}{ll}3 & 1 \\
4 & \end{array}$ & $\begin{array}{ll}\text { C } & 12 \\
\text { Si } & 28\end{array}$ & $\begin{array}{ll}1 & 3 \\
4 & \end{array}$ \\
\hline
\end{tabular}

The difference of 16 in the atomic weights does not correspond to a constant difference in the density-numbers; but a difference of 45 to 48 corresponds to 5 , as is seen in Table VII. In the last pair $(\mathrm{Ag}, \mathrm{Tl})$ the differences are doubled.

Table VII.

\begin{tabular}{|c|c|c|c|c|c|}
\hline $\begin{array}{l}\text { Atomic } \\
\text { weight. }\end{array}$ & $\begin{array}{l}\text { Density- } \\
\text { number. }\end{array}$ & $\begin{array}{l}\text { A tomic } \\
\text { weight. }\end{array}$ & $\begin{array}{l}\text { Density- } \\
\text { number. }\end{array}$ & $\begin{array}{l}\text { Atomic } \\
\text { weight. }\end{array}$ & $\begin{array}{l}\text { Density- } \\
\text { number. }\end{array}$ \\
\hline $\mid \begin{array}{cc}C u & 63.5 \\
\text { g } & 108\end{array}$ & $\begin{array}{ll}11 & \\
16 & 5\end{array}$ & $\mid \begin{array}{l}\text { Zn } 65 \cdot 5 \\
\text { Cd } 112\end{array}$ & $\begin{array}{ll}11 & 5 \\
16 & \end{array}$ & $\begin{array}{cc}\text { Ag } & 108 \\
96 \\
\text { T1 } & 204\end{array}$ & $\begin{array}{ll}16 & \\
& 10 \\
26 & \end{array}$ \\
\hline
\end{tabular}


Again, comparing the pairs $\mathrm{Hg}$ and $\mathrm{Zn}$, which are diad in compounds such as $\mathrm{Zn}\left(\mathrm{C}_{2} \mathrm{H}_{5}\right)_{2}$, and $\mathrm{Pb}$ and $\mathrm{Sn}$, which are

TABLE VIII.

\begin{tabular}{|c|c|c|c|}
\hline $\begin{array}{l}\text { Atomic } \\
\text { weight. }\end{array}$ & $\begin{array}{l}\text { Density- } \\
\text { number. }\end{array}$ & $\begin{array}{l}\text { Atomic } \\
\text { weight. }\end{array}$ & $\begin{array}{l}\text { Density- } \\
\text { number. }\end{array}$ \\
\hline $\begin{array}{l}\text { Zn } \\
H_{g} \\
200\end{array}$ & $\begin{array}{ll}11 & \\
26 & 15\end{array}$ & $\begin{array}{l}\mathrm{Sn} 118 \\
\mathrm{~Pb} 207\end{array}$ & $\begin{array}{ll}14 & \\
29 & 15\end{array}$ \\
\hline
\end{tabular}

tetrad in corresponding compounds, we find that in the first pair, where the difference in the atomic weights $135=3 \times 45$, that in the density-numbers $=15=3 \times 5$; but that this is not the case with lead and tin; for while the difference in atomic weights $(=89=2 \times 45)$ is double, the difference in density-numbers is treble. In time, I trust, as the gaps in Table I. are filled up, it will be possible to extend and generalize considerations of the above nature.

After this digression I shall return to the application of the law to hydrated crystals, and shall apply it to the results of the well-known experiments of Schiff on the density of alums and isomorphous sulphates.

\section{TABLE IX.}

Experiments of Schiff.

\begin{tabular}{|c|c|c|c|c|}
\hline Salts. & & B. & $\delta$. & $k$. \\
\hline $\begin{array}{l}\text { (a) Alums:- } \\
\text { AlK }\left(\mathrm{SO}_{4}\right)_{2} \\
12 \mathrm{H}_{2} \mathrm{O} \\
\text { AlNa }\left(\mathrm{SO}_{4}\right)_{2} \quad " \\
\text { CrK }\left(\mathrm{SO}_{4}\right)_{2} \quad "\end{array}$ & \begin{tabular}{l|} 
\\
$\cdots$ \\
$\cdots \cdots$ \\
$\cdots \cdots$
\end{tabular} & $\begin{array}{l}57 \\
56 \\
62\end{array}$ & $\begin{array}{l}1.722 \\
1.641 \\
1.845\end{array}$ & $\begin{array}{l}33 \cdot 1 \\
34 \cdot 1 \\
33 \cdot 6\end{array}$ \\
\hline 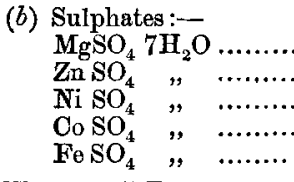 & ….. & $\begin{array}{l}32 \\
38 \\
38 \\
38 \\
36\end{array}$ & $\begin{array}{l}1.685 \\
1.953 \\
1.951 \\
1.924 \\
1.884\end{array}$ & $\begin{array}{l}19 \cdot 0 \\
19 \cdot 5 \\
19 \cdot 7 \\
19 \cdot 8 \\
19 \cdot 1\end{array}$ \\
\hline 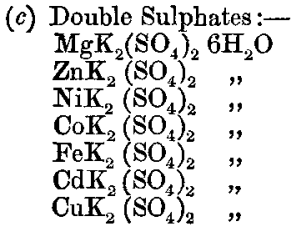 & \begin{tabular}{l|}
$\ldots \ldots .$. \\
$\ldots \ldots$. \\
$\ldots \ldots$. \\
$\cdots \ldots .$. \\
$\cdots \ldots$. \\
$\cdots \cdots$.
\end{tabular} & $\begin{array}{l}45 \\
51 \\
51 \\
51 \\
49 \\
56 \\
51\end{array}$ & $\begin{array}{l}1 \cdot 995 \\
2 \cdot 153 \\
2 \cdot 123 \\
2 \cdot 154 \\
2 \cdot 189 \\
2 \cdot 438 \\
2 \cdot 137\end{array}$ & $\begin{array}{l}22 \cdot 4 \\
23 \cdot 7 \\
24 \cdot 0 \\
23 \cdot 7 \\
22 \cdot 4 \\
23 \cdot 0 \\
23 \cdot 9\end{array}$ \\
\hline
\end{tabular}


I have omitted from the table the data for the compounds in which potassium is replaced by ammonium. The value of $k$ is here also constant, but slightly greater than that for the potassium compounds. The salts here considered have approximately equal molecular volumes*. Thus the alums are thus related :-

\begin{tabular}{|l|c|c|c|c|}
\hline & $\begin{array}{c}\text { Atomio } \\
\text { weight. }\end{array}$ & $\delta$. & $\begin{array}{c}\text { Molecular } \\
\text { volume. }\end{array}$ \\
\hline $\mathrm{AlK}\left(\mathrm{SO}_{4}\right)_{2} 12 \mathrm{H}_{2} \mathrm{O}$ & $\ldots \ldots$. & 474 & 1.722 & $275 \cdot 3$ \\
$\mathrm{AlNa}\left(\mathrm{SO}_{4}\right)_{2} 12 \mathrm{H}_{2} \mathrm{O}$ & $\ldots \ldots$ & 458 & 1.641 & $279 \cdot 1$ \\
$\mathrm{CrK}\left(\mathrm{SO}_{4}\right)_{2} 12 \mathrm{H}_{2} \mathrm{O}$ & $\ldots . .$. & 499 & 1.845 & 270.5 \\
\hline
\end{tabular}

Application of the Law to Bodies in Vapour at the Boiling-point.

If the boiling-point be $s^{\circ}$ Centigrade, and $\mathrm{D} s$ be the density of the vapour at that temperature, the pressure being 760 millim., then $\mathrm{T}=273+s^{\circ}$; and the laws of Avogadro and GayLussac may be expressed thus :-

$$
\frac{\mathrm{D} s}{\mathrm{D}^{\prime} s^{\prime}}=\frac{a}{a^{\prime}} \times \frac{\mathrm{T}^{\prime}}{\mathrm{T}}
$$

On the other hand, the law of density-numbers gives

Hence it follows that

$$
\frac{\mathrm{D} s}{\mathrm{D}^{\prime} s^{\prime}}=\frac{\mathrm{B}}{\mathrm{B}^{\prime}}
$$

$$
\frac{\mathrm{TB}}{a}=\text { constant }
$$

or, for bodies containing only carbon, hydrogen, and oxygen,

$$
\frac{\mathrm{T} \times n}{a}=\text { constant (see above). }
$$

* The equality (approximate) of the molecular volumes of isomorphous bodies, which was long ago recognized, may be regarded as to some extent an anticipation of the law of density-numbers, and may be explained as follows:-

The constants $k=\frac{\mathrm{B}}{\delta}$ are equal according to the law. In certain cases (such as the salts in the table) the relation $\left(\begin{array}{l}a \\ \bar{B}\end{array}\right)$ between the atomic weight and the density-numbers is nearly the same for different members of the same group; hence it follows that the values of $\frac{a}{\delta}$ (that is, the molecular volumes) are approximately equal. 
The value of this constant for water (density-number $=3$ ) is

$$
\frac{273+100 \times 3}{18}=62 \cdot 2 \text {. }
$$

In Table $\mathrm{X}$. are given the data relating to 13 substances which contain $\mathrm{C}_{p} \mathrm{H}_{q} \mathrm{O}_{r}$, the value of $q$ being in the first group 10 , in the second 8 .

TABLE X.

Constant $\mathrm{T} n / a=62 \cdot 2$.

\begin{tabular}{|c|c|c|c|c|c|c|}
\hline Name. & Formula. & a. & $n$. & So. & T. & $\operatorname{Tn} / a$. \\
\hline Ethylic ether..... & $\mathrm{C}_{4} \mathrm{H}_{10} \mathrm{O}$ & 74 & 15 & 34 & 308 & $62 \cdot 4$ \\
\hline Ethyl allyl ether. & $\mathrm{C}_{5} \mathrm{H}_{10} \mathrm{O}$ & 86 & 16 & 64 & 337 & $62 \cdot 7$ \\
\hline Ethyl propionate... & $\mathrm{C}_{5}^{3} \mathrm{H}_{10} \mathrm{O}_{2}$ & 102 & 17 & 100 & 373 & $62 \cdot 2$ \\
\hline Ethyl carbonate .. & $\mathrm{C}_{5}^{3} \mathrm{H}_{10}^{10} \mathrm{O}_{3}^{2}$ & 118 & 18 & 126 & 399 & $60 \cdot 9$ \\
\hline Allylic ether ........ & $\mathrm{C}_{6}^{3} \mathrm{H}_{10}^{10} \mathrm{O}^{3}$ & 98 & 17 & 86 & 359 & $62 \cdot 3$ \\
\hline Allylic propionate & $\mathrm{C}_{6}^{6} \mathrm{H}_{10} \mathrm{O}_{2}$ & 114 & 18 & 123 & 396 & $62 \cdot 5$ \\
\hline Ethylic oxalate ..... & $\mathrm{C}_{8} \mathrm{H}_{10} \mathrm{O}_{4}^{2}$ & 146 & 20 & 196 & 459 & $62 \cdot 9$ \\
\hline Allyl oxalate........ & $\mathbf{O}_{8} \mathbf{H}_{10}^{10} \mathrm{O}_{4}$ & 170 & 22 & 206 & 479 & $62 \cdot 0$ \\
\hline Toluene & $\mathrm{C}_{7} \mathrm{H}_{8}$ & 92 & 15 & 108 & 381 & $62 \cdot 1$ \\
\hline Anisol ................ & $\mathrm{C}_{\gamma}^{7} \mathrm{H}_{8} \mathrm{O}$ & 103 & 16 & 150 & 423 & $62 \cdot 6$ \\
\hline Ethyl pyromuconate & $\mathrm{C}_{7}^{7} \mathrm{H}_{8}^{8} \mathrm{O}_{3}$ & 140 & 18 & 209 & 452 & $62 \cdot 0$ \\
\hline Methyl benzoate .... & $\mathrm{C}_{5} \mathrm{H}_{3} \mathrm{O}_{2}^{3}$ & 136 & 18 & 198 & 471 & $62 \cdot 3$ \\
\hline Methyl salicylate .......... & $\mathrm{C}_{8} \mathrm{H}_{8}^{3} \mathrm{O}_{3}^{2}$ & 152 & 19 & 223 & 496 & $62 \cdot 0$ \\
\hline
\end{tabular}

Table XI. comprises substances with fourteen atoms of hydrogen. The constant $\frac{T n}{a}$ is different from that in Table $\mathrm{X}$., but is here the same for all the bodies.

TABLE XI.

\begin{tabular}{|c|c|c|c|c|c|c|c|c|}
\hline Names. & c. & $\mathbf{H}$. & 0. & a. & $n$. & $\mathbf{S}^{\circ}$. & $\begin{array}{l}\text { Autho- } \\
\text { rities. }\end{array}$ & Tnja. \\
\hline Hexane ........... & 6 & 14 & & 86 & 20 & 45 & Go.* & 73.9 \\
\hline Ethyl propylate & 6 & 14 & 1 & 102 & 21 & 85 & Ch. & $73 \cdot 7$ \\
\hline Diethyl glycol ... & 6 & 14 & 2 & 118 & 22 & 123 & Wö. & 739 \\
\hline Ethyl valerate. & 7 & 14 & 2 & 130 & 23 & 143 & Li. & $73 \cdot 6$ \\
\hline Allyl valerate.............. & 8 & 14 & 2 & 142 & 24 & 165 & Wü. & $74 \cdot 0$ \\
\hline Ethyl ethylacetocarbonate. & 8 & 14 & 3 & 158 & 25 & 195 & Wö. & $74 \cdot 0$ \\
\hline Ethyl suceinate............... & 8 & 14 & 4 & 174 & 26 & 217 & Kp. & $73 \cdot 2$ \\
\hline Diethylene diacetate... & 8 & 14 & 5 & 190 & 27 & 248 & Wö. & $74 \cdot 0$ \\
\hline Allyl acetoacetate & 9 & 14 & 3 & 170 & 26 & 206 & Wö. & $73 \cdot 3$ \\
\hline Ethyl itaconate................... & 9 & 14 & 4 & 186 & 27 & 227 & Ke. & $72 \cdot 6$ \\
\hline
\end{tabular}

Mean value of $\frac{\mathrm{T} n}{a}=736$.

* Go. means Goriainow ; Ch. = Chancel; Wö. = Dictionary Fehling ; Li. = Linnemann; Wü. = Dictionary Würtz; Kp. = Kopp; Ke. = Kékulé, Lehrbuch. 
Connection between the different Values of the Constant $\frac{\mathrm{T} n}{a}$.

In an homologous series one observes generally certain properties common to all the members ; e. g.:-

(1) A regular increase in the boiling-points of the successive members of the same series.

(2) The amount of this increase varies slightly, but is from $16^{\circ}$ to $20^{\circ}$ for every addition of the group $\mathrm{CH}_{2}$. It was formerly supposed that the differences were equal; but, so far as experiment has gone, we are able to point to only approximate equality.

In order to apply the law of density-numbers to homologous series, it will be convenient to number the members of a series $1,2,3, \& c .$, according to the place in the series occupied by each. I shall call these numbers $m$ : thus benzol has $m=4$; it is therefore the fourth member of its series according to the new Isaw, though at present the first one known*.

Table XI. contains the substances each containing fourteen atoms of hydrogen ; each is the seventh member of its respective series, for $m$ here equals 7 . Such substances I shall call "corresponding" compounds. They have, as a rule, similar properties, and have frequently the same constants Tn/a.

I may now sum up the results of observations on the constants $\frac{\mathrm{T} n}{a}$ as follows :-

(1) These constants, of which we have already met two $(62 \cdot 2$ and $73 \cdot 6)$, form an algebraic series of numbers which are the same for all bodies, whether metals or non-metals, and their compounds.

(2) In an homologous series the constants increase with the successive additions of $\mathrm{CH}_{2}, i$. $e$. with the value of $m$.

(3) There are numerous homologous series the corresponding members of which possess the same constant, e. g. :-
a. Ethers . . $\mathrm{C}_{n} \mathrm{H}_{2 n} \mathrm{O}_{2}$,
ß.,$\quad$. $\mathrm{C}_{n} \mathrm{H}_{2 n-2} \mathrm{O}_{4}$.
r. $\quad$. . $\mathrm{C}_{n} \mathrm{H}_{2 n+2} \mathrm{O}$.

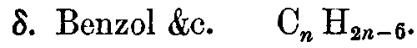

* M. Groshans has not made it quite clear how he obtains the numbers $m$ otherwise than by experiment. They are found in compounds of carbon, hydrogen, and oxygen by dividing the carbon and hydrogen by the group $\mathrm{CH}_{2}$ and adding one to the number thus obtained; the residue left, after deducting all the $\mathrm{CH}_{2}$ groups, being the first body: thus ether, $\mathrm{C}_{1} \mathrm{H}_{10} \mathrm{O}$, is the titth, for it $=4\left(\mathrm{CH}_{2}\right)+\mathrm{H}_{2} \mathrm{O}$, and $\mathrm{H}_{2} \mathrm{O}$ is the first of the series $\mathrm{C}_{n} \mathrm{H}_{2 n+2} \mathrm{O}$. - Translator. 
(4) A comparison of the constants of these four series and of many others has shown that it is possible to express the series of constants $\frac{\mathrm{T} n}{a}$ by the formula

$$
\frac{\mathrm{T} n}{a}=27 \cdot 8 \cdot \sqrt{x},
$$

where $x=1,2,3,4, \& c$.

(5) In the four series above,

but in other series,

$$
x=m \text {; }
$$

$$
x=m+y,
$$

$y$ being a small number ; thus, in the ethylic alcohol series,

$$
x=m+3 \text {. }
$$

The constant $\frac{\mathrm{T} n}{a}$ in Table X. corresponds to $x=5$. It is also the constant for water, and it is for this reason that $I$ have adopted the value $27 \cdot 8$. For with water we have

$$
(273+100) \frac{3}{18} \times \frac{1}{\sqrt{5}}=27 \cdot 801 .
$$

On this basis are calculated the constants for various values of $x$ given in Table XII.

\section{TABLE XII.}

\begin{tabular}{|c|c||c|c||c|c|}
\hline$x$. & Tn/a. & $x$. & Tn/a. & $x$. & Tn/a. \\
\hline 1. & $27 \cdot 80$ & 4. & $55 \cdot 60$ & 7. & 73.56 \\
2. & $39 \cdot 32$ & 5. & $62 \cdot 17$ & 8. & $78 \cdot 63$ \\
3. & $48 \cdot 15$ & 6. & $68 \cdot 10$ & 9. & $83 \cdot 41$ \\
\hline
\end{tabular}

In the following table are given the boiling-points, observed and calculated, for the first sixteen ethers of the series $\mathrm{C}_{n} \mathrm{H}_{2 n} \mathrm{O}_{2}$.

The formula used in the calculation is

$$
\mathrm{T}=(273+s)=\frac{a}{n} 27 \cdot 8 \sqrt{m}
$$




\section{TABLE XIII.}

Boiling-points (s), observed and calculated, for the Ethers $\mathrm{C}_{n} \mathrm{H}_{2 n} \mathrm{O}_{2}$.

\begin{tabular}{|c|c|c|c|c|c|c|c|c|}
\hline$m$. & \multicolumn{2}{|l|}{ Formulæ. } & a. & n. & $\begin{array}{c}\mathbf{S}^{\circ}, \\
\text { observed }\end{array}$ & $\begin{array}{c}\mathrm{S}^{\circ}, \\
\text { ealeulated }\end{array}$ & $\begin{array}{l}\text { Differ- } \\
\text { ences. }\end{array}$ & $\begin{array}{l}\text { Autho- } \\
\text { rities. }\end{array}$ \\
\hline 1. & $\left(\begin{array}{ll}C & \mathrm{H}_{2}\end{array}\right)$ & & 46 & 5 & & $-17 \cdot 2$ & & \\
\hline 2. & $\mathrm{C}_{2} \mathrm{H}_{4} \mathrm{O}_{2}$ & .... & 60 & 8 & 33 & $+21 \cdot 8$ & 39 & Kp.* \\
\hline 3. & $\mathrm{C}_{3} \mathrm{H}_{6}^{2} \mathrm{O}_{2}^{-}$ & ...... & 74 & 11 & 53 & $51 \cdot 0$ & $\begin{array}{l}292 \\
25.6\end{array}$ & Pí. \\
\hline 4. & $\mathrm{C}_{4} \mathrm{H}_{8} \mathrm{O}_{2}$ & ....... & 88 & 14 & 77 & $76 \cdot 6$ & $\begin{array}{l}200 \\
23.4\end{array}$ & Ii. \\
\hline 5. & $\mathrm{O}_{5} \mathrm{H}_{10} \mathrm{O}_{2}$ & ....... & 102 & 17 & 100 & 100 & $22 \cdot 0$ & Pu. \\
\hline 6. & $\mathrm{O}_{6} \mathrm{H}_{12} \mathrm{O}_{2}$ & ....... & 116 & 20 & 122 & 1220 & 220 & Li. \\
\hline 7. & $\mathrm{C}_{7} \mathrm{H}_{14}^{2} \mathrm{O}_{2}$ & ...... & 130 & 23 & 143 & $142 \cdot 7$ & $\begin{array}{l}207 \\
19 \cdot 8\end{array}$ & $\mathrm{Li}$. \\
\hline 8. & $\mathrm{C}_{8} \mathrm{H}_{16}^{27} \mathrm{O}_{2}^{-}$ & ...... & 144 & 26 & 162 & $162 \cdot 5$ & 19.0 & Fe. \\
\hline 9. & $\mathrm{C}_{9} \mathrm{H}_{18} \mathrm{O}_{2}$ & ....... & 158 & 29 & 176 & 181.5 & 180 & Wö. \\
\hline 10. & $\mathrm{O}_{10} \mathrm{H}_{20} \mathrm{O}_{2}$ & ....... & 172 & 32 & 200 & $199 \cdot 6$ & $17 \cdot 4$ & Seh. \\
\hline 11. & $\mathrm{C}_{11} \mathrm{H}_{22}^{-} \mathrm{O}_{2}$ & ....... & 186 & 35 & 217 & $217 \cdot 0$ & 16.9 & Ca. \\
\hline 12. & $\left(\mathrm{O}_{12}^{11} \mathrm{H}_{24}^{2} \mathrm{O}_{2}^{2}\right)$ & ..... & 200 & 38 & & 233.9 & $\begin{array}{l}16.9 \\
16.4\end{array}$ & \\
\hline 13. & $\mathrm{C}_{13} \mathrm{H}_{26} \mathrm{O}_{2}$ & ...... & 214 & 41 & 250 & $250 \cdot 3$ & $\begin{array}{l}104 \\
158\end{array}$ & Zi. \\
\hline 14. & $\mathrm{C}_{14} \mathrm{H}_{28} \mathrm{O}_{2}$ & ...... & 228 & 44 & 269 & $266 \cdot 1$ & $15 \cdot 4$ & Zi. \\
\hline 10. & $\left(\mathrm{C}_{15} \mathrm{H}_{30} \mathrm{O}_{2}\right)$ & $\cdots \cdots$ & 256 & $\begin{array}{l}47 \\
50\end{array}$ & 298 & 2815 & $15 \cdot 2$ & $Z_{i}$ \\
\hline & $\mathrm{U}_{16} \mathrm{D}_{32} \mathrm{O}_{2}$ & $\cdots$ & 2000 & 50 & 298 & $290 \%$ & & \\
\hline
\end{tabular}

\section{Table XIV.}

Boiling-points, calculated and observed, of Benzol and its Homologues.

\begin{tabular}{|c|c|c|c|c|c|c|c|c|}
\hline$m$ & Name. & Formula. & $a$. & $n$. & $\begin{array}{c}\mathbf{S}^{\circ}, \\
\text { observed. }\end{array}$ & $\begin{array}{c}\mathbf{S}^{\circ}, \\
\text { calculated. }\end{array}$ & $\begin{array}{l}\text { Differ- } \\
\text { ences } \\
\text { of } s^{\circ} \text {. }\end{array}$ & $\begin{array}{l}\text { Autho- } \\
\text { rities. }\end{array}$ \\
\hline 1. & …... & & 36 & 3 & ....... & 607 & & \\
\hline 2. & & $\mathrm{C}_{4}^{8} \mathrm{H}_{2}$ & 50 & 6 & ..... & 547 & $15 \cdot 1$ & \\
\hline 3. & …..... & $\mathrm{O}_{5} \mathrm{H}_{4}$ & 64 & 9 & 85 & $\begin{array}{l}69 \cdot 8 \\
88.5\end{array}$ & $18 \cdot 7$ & \\
\hline 5. & Toluol & $\begin{array}{l}\mathrm{C}_{6} \mathrm{H}_{6} \\
\mathrm{C} \mathrm{H}^{-}\end{array}$ & $\begin{array}{l}78 \\
90\end{array}$ & 12 & $\begin{array}{r}80 \\
108\end{array}$ & $\begin{array}{r}80.0 \\
108 \cdot 4\end{array}$ & $19 \cdot 0$ & Henry. \\
\hline 6. & Xylol .. & $\mathrm{C}_{8}^{7} \mathbf{H}_{10}^{8}$ & 106 & 18 & 129 & $128 \cdot 1$ & 197 & Cahours. \\
\hline 7. & Cumol & $\mathrm{C}_{9}^{8} \mathrm{H}_{12}^{10}$ & 120 & 21 & 152 & $147 \cdot 5$ & 194 & Gerhardt. \\
\hline 8. & Cymol & $\mathrm{C}_{10} \mathrm{H}_{11}$ & 134 & 24 & 171 & 166.2 & & Noad. \\
\hline 9. & Laurol & $\mathrm{C}_{12} \mathrm{H}_{18}$ & 148 & 27 & 188 & $184 \cdot 2$ & & Fittig. \\
\hline
\end{tabular}

In the columns headed " differences" in the last two tables I have given the increase of calculated boiling-point for each successive member of the series, and a similar relationship is to be found in the case of other series. Thus, in :-

* Kp. stands for Kopp; Pi. = Pierre; Li. $=$ Limnemann; Pu. $=$ Puchot; Fe. = Fehling; Wö. = Wörterbuch (dictionary) Fehling Sch. $=$ Schorlemmer $;$ Ca. $=$ Cahours $; \mathrm{Zi} .=$ Zincke. 
(1) The Ethers $\mathrm{C}_{n} \mathrm{H}_{2 n+2} \mathrm{O}$, beginning with $\mathrm{C}_{3} \mathrm{H}_{8} \mathrm{O}$, where $x$ is equal to $m=4$, the differences are:-

$27 \cdot 6, \quad 26 \cdot 3, \quad 24 \cdot 5, \quad 22 \cdot 8, \quad 21 \cdot 3,20 \cdot 5, \quad 19 \cdot 5$.

(2) The series beginning with Methyl Benzoate, $\mathrm{C}_{8} \mathrm{H}_{8} \mathrm{O}_{2}$, where $x=m=5$,

$$
16 \cdot 7,16 \cdot 2,15 \cdot 8,15 \cdot 4,15 \cdot 0 \text {. }
$$

(3) The Alcohol series $\mathrm{C}_{n} \mathrm{H}_{2 n+2} \mathrm{O}$, beginning with $\mathrm{CH}_{4} \mathrm{O}$, where $x=m+3=5$,

$$
16 \cdot 6, \quad 19 \cdot 6, \quad 20 \cdot 2,19 \cdot 8,19 \cdot 4,18 \cdot 6,17 \cdot 9 \text {. }
$$

The first three substances in Table XIV. do not exist, and it is very commonly found that the first members of homologous series, those corresponding to $m=(1),(2),(3)$, are wanting. There are, however, cases where similar bodies are to be met with : thus the series $\mathrm{C}_{n} \mathrm{H}_{2 n+2}$ gives rise by substitution to $\mathrm{C}_{n} \mathrm{H}_{2 n+1} \mathrm{Cl}$ and $\mathrm{C}_{n} \mathrm{H}_{2 n} \mathrm{Cl}_{2}$. And all the corresponding members of the three series possess the same constants : $\mathrm{T} n / a$ (or $\mathrm{T} \mathrm{B} / a$ ) and $\mathrm{V} s n / a$ (or Vs B/a).

The first members of the substituted series are chlorine and hydrochloric acid, which both have $x=1$ *

As a general rule, the value of $x$ is a whole number, but it sometimes happens that this is not the case. Thus, $x=3 \frac{1}{2}$ for acetic acid, $\mathrm{C}_{2} \mathrm{H}_{4} \mathrm{O}_{2}$; acetic anhydride, $\mathrm{C}_{4} \mathrm{H}_{6} \mathrm{O}_{3}$; and a similar substance differing from the anhydride in possessing one atom of oxygen more, $\mathrm{C}_{4} \mathrm{H}_{6} \mathrm{O}_{4}$, methyl oxalate. All the three are well known to behave anomalously. Thus the vapour-density of acetic acid is abnormal. All three are solid at temperatures below which their higher homologues are still liquid; and, finally, the aqueous solution of acetic acid is remarkable for possessing a maximum of density at 80 per cent.

[To be continued.]

* With regard to gases such as oxygen, and some others such as CO, $\mathrm{CO}_{2}, \mathrm{SO}_{2}, \mathrm{CS}_{2}, \& c$., we find that the value of $x$ is a fraction much less than unity.

Just as experiment has shown that there are cases to which the laws of Avogadro and those analogous to it are not applicable, so we find similar cases in which the law of density-numbers no longer holds good. 